\title{
EFEKTIVITAS PROJECT BASED LEARNING TERHADAP KETERAMPILAN MENULIS BAHAN AJAR IPA CALON GURU SD Oleh:
}

Susilawati ${ }^{1}$, Widia Nur Jannah ${ }^{2}$, Dianasari ${ }^{3}$. Universitas Muhammadiyah Cirebon

\begin{abstract}
The purpose of this research is to analyze the effectiveness of Project Based Learning (PjBL) of writing skills on Science teaching materials to elementary school teachers candidates.This research used experimental methods (single-one group pretest-posttest design) with instruments such as portofolio assessment sheets, observation sheets, and questionnaire sheets. The effectiveness of analyzing used n-gain and t-test.The subject of this research is elementary school teachers candidates who contracted "Science Learning"subject in a program study teacher education of elementary school at University Muhammadiyah Cirebon. The findings of this study has produced a contextual book for Science teaching material. In addition, there is an increased of elementary school teachers candidates who prepared the teaching materials in a printed form relevant to the needs and characters of the students as well as the curriculum. It is proven by assessments that the ability rose significantly from 2,71 (category is adequate skill) to 3,83 (category is skilled) and supported by the n-gain value at 0,87. Based on the t-test count of 8,050 larger than t-table 2,045. Recommendations from this research is that PjBL as a learning model could become one of the alternative learning models to improve writing skills material for elementary school teachers candidates.
\end{abstract}

Keyword: Project-Based-Learning, science-materials-teaching, elementary-schoo-teacherscandidates.

\begin{abstract}
Abstrak: Tujuan penelitian ini untuk menganalisis efektivitas Project Based Learning (PjBL) terhadap keterampilan menulis bahan ajar IPA Calon Guru SD. Penelitian ini menggunakan metode eksperimen (Single-One Group Pretest-Posttest Design) dengan menggunakan instrumen berupa lembar penilaian portofolio, lembar observasi, dan lembar angket. Efektivitas dianalisis menggunakan n-gain dan uji T. Subjek penelitian ini adalah mahasiswa calon guru yang mengontrak matakuliah Pembelajaran IPA di Program Studi Pendidikan Guru Sekolah Dasar (PGSD) Universitas Muhammadiyah Cirebon. Temuan penelitian ini telah menghasilkan buku ajar cetak IPA yang kontekstual. Selain itu, keterampilan calon guru dalam menyusun bahan ajar cetak yang relevan dengan kebutuhan dan karakter siswa serta kurikulum yang berlaku juga meningkat. Hal ini dibuktikan dengan hasil penilaian yang meningkat signifikan dari 2,71 (kategori cukup terampil) menjadi 3,83 (kategori terampil) serta didukung oleh hasil n-Gain yang tinggi yaitu 0,87 . Selain itu berdasarkan uji T diketahui bahwa t hitung sebesar 8,050 lebih besar dari $\mathrm{t}$ tabel yaitu 2,045. Rekomendasi dari penelitian ini model PjBL dapat dijadikan salah satu alternatif model pembelajaran untuk meningkatkan keterampilan menulis bahan ajar mahasiswa calon guru SD.
\end{abstract}

Kata Kunci: Project-Based-Learning, Bahan Ajar IPA, Calon Guru SD.

\section{PENDAHULUAN}

Bahan ajar memiliki posisi yang sangat penting dalam pembelajaran, yaitu sebagai representasi (wakil) dari penjelasan guru di depan kelas. Penguasaan bahan ajar memudahkan guru dalam mencapai tujuan pembelajaran. Sebaliknya, guru yang tidak menguasai bahan ajar menyebabkan pembelajaran kurang efektif dan interaktif serta tujuan pembelajaran lebih sulit dicapai. Ghanney (2008) menjelaskan hasil penelitiannya "study revealed that inability of teachers to use instructional materials leads to: pupils becoming passive listeners in class, boredom, poor participation in

\footnotetext{
${ }^{1}$ Universitas Muhammadiyah Cirebon, Emai:susilawatisaefudin@gmail.com

${ }^{2}$ Universitas Muhammadiyah Cirebon, Email: widianurjannah87@gmail.com

${ }^{3}$ Universitas Muhammadiyah Cirebon, Email: ceritadiana@yahoo.com
} 
lesson, lack of interest in the subject, absenteeism and finally poor performance in the subject matter". Oleh karena itu, guru yang tidak menguasai bahan ajar menjadikan peserta didik pasif, bosan, dan kurang berminat dalam mengikuti pembelajaran di kelas.

Undang-Undang Sistem Pendidikan Nasional No. 20 tahun 2003 Pasal 40 Ayat 2 menjelaskan bahwa kewajiban guru dalam pembelajaran di kelas adalah menciptakan suasana pendidikan yang bermakna, kreatif, dinamis, dan dialogis dan mempunyai komitmen secara profesional untuk meningkatkan mutu pendidikan. Hal tersebut merupakan bagian dari kompetensi professional yang harus dikuasai oleh seorang guru.

Jika merujuk pada Undang-undang tersebut maka Guru yang profesional tidak hanya terampil menguasai bahan ajar, tetapi memiliki keterampilan menulis bahan ajar. Hal ini disebabkan kebutuhan dan karakteristik peserta didik di sekolah berbeda-beda sehingga calon guru perlu dibekali dengan keterampilan menulis bahan ajar agar dapat menciptakan suasana pembelajaran yang efektif dan menyenangkan.

Kurangnya kemampuan guru dalam menampilkan bahan ajar di kelas secara efektif dan menyenangkan, didukung oleh kurangnya keterampilan guru dalam mengemas bahan ajar secara mandiri. Bahan ajar yang selama ini ditampilkan oleh guru di kelas umumnya didapatkan dari buku teks pelajaran yang sudah disediakan oleh pemerintah atau dari berbagai penerbit sehingga kadang tidak sesuai dengan kebutuhan belajar peserta didik di sekolahnya. Hal ini disebabkan setiap sekolah memiliki kultur dan karakteristik yang berbeda.

Sukerni (2014) dalam penelitiannya mengemukakan "Berdasarkan analisis kebutuhan para guru membutuhkan buku ajar yang sesuai dengan karakteristik dan kebutuhan siswa dalam belajar". Namun, banyak guru yang belum memiliki keterampilan menulis sesuai dengan yang diharapkan. Hal ini dikemukakan Sembiring (2007) "jumlah penerbitan buku yang ditulis oleh guru relatif masih kurang dibandingkan dengan jumlah guru ada sekitar 2,7 juta orang". Selain itu, hasil penelitian yang dilakukan oleh Sinaga (2015) juga mengemukakan "masalah yang teridentifikasi pada studi lapangan ialah rendahnya kemampuan dan keterampilan guru dalam menulis bahan ajar".

Di sisi lain, pengembangannya konten materi misalnya dalam mata pelajaran IPA juga belum diaplikasikan oleh guru sesuai dengan karakter dan kebutuhan peserta didik dalam kehidupan sehari-hari. Sukerni (2014) mengungkapkan "permasalahan yang sering terjadi di sekolah yang berkaitan dengan proses belajar mengajar adalah: kajian materi setiap buku ajar bervariasi, materi yang terdapat dalam buku ajar tidak sesuai dengan karakteristik siswa. Kondisi ini yang memacu melakukan kegiatan pengadaan buku yang relevan dengan mata pelajaran dan sesuai dengan karakteristik dan kebutuhan siswa dan gambar-gambar pembelajaran yang sesuai dengan karakteristik dan kebutuhan siswa". Oleh karena itu, seorang calon guru perlu dibekali keterampilan menulis sehingga dapat menyusun dan mengembangkan kemampuannya dalam menulis bahan ajar sehingga dapat memfasilitasi peserta didik untuk mengeksporasi pengetahuan dengan proses sains secara lebih baik.

Salah satu alternatif yang dapat dilakukan untuk mengembangkan keterampilan menulis calon guru adalah menggunakan pembelajaran berbasis proyek atau Project Based Learning (PjBL). PjBL dapat memfasilitasi calon guru untuk dapat menulis bahan ajar sehingga sesuai dengan tujuan pembelajaran yang diharapkan. Tiantong, M \& Sumalee Siksen (2013) mengemukakan "PjBL has been found to be effective to increase student learning achievement, acquiring knowledge through active learning, gaining interdisciplinary and multidisciplinary knowledge". Model PjBL dapat meningkatkan berbagai

Susilawati , Widia Nur Jannah , Dianasari: Efektivitas Project Based Learning terhadap Keterampilan 
keterampilan dan memberikan pengalaman pembelajaran aktif. Melalui PjBL diharapkan keterampilan menulis bahan ajar calon guru Sekolah Dasar (SD) akan lebih baik sehingga kualitas pembelajaran yang didapatkan sesuai dengan tujuan pendidikan nasional.

Berdasarkan uraian di atas, maka perlu dilakukan penelitian untuk melihat efektivitas dari model Project Based Learning (PjBL) terhadap keterampilan menulis bahan ajar mahasiswa calon guru SD.

\section{TINJUAN PUSTAKA}

1. Project Based Learning (PjBL)

Project Based Learning (PjBL) merupakan salah satu pembelajaran dengan menggunakan proyek sebagai langkah untuk mencapai tujuan pembelajaran. Thomas, dkk (Wena, 2011) mengemukakan kerja proyek yang dimaksud memuat tugastugas yang kompleks berdasarkan kepada pertanyaan dan permasalahan yang sangat menantang, dan menuntut peserta didik untuk merancang, memecahkan masalah, membuat keputusan, melakukan kegiatan investigasi, serta memberikan kesempatan kepada peserta didik untuk bekerja mandiri. Tujuannya adalah agar peserta didik mempunyai kemandirian dalam menyelesaikan tugas yang dihadapinya.

Moursound dalam Wena (2011) mengemukakan beberapa kelebihan dari implementasi pembelajaran PjBL, yaitu: 1) increased motivation, meningkatkan motivasi belajar siswa, 2) increased problem-solving ability, meningkatkan kecakapan siswa dalam pemecahan masalah, 3) improved library research skills, meningkatkan keterampilan memperoleh informasi melalui sumbersumber informasi, 4) increased collaboration, meningkatkan semangat dan keterampilan berkolaborasi/bekerjasama, 5) increased resource management skills, meningkatkan keterampilan dalam manajemen sumber daya. Oleh karena itu, pembelajaran ini perlu diimplementaskan dengan membagi peserta didik menjadi beberapa kelompok untuk menyelesaikan sebuah proyek sehingga memunculkan motivasi, kecakapan, keterampilan dalam menyelesaikan masalah. Selain itu, Wang, dkk (2015) juga menungkapkan bahwa $\mathrm{PjBL}$ dapat meningkatkan kemampuan menulis siswa.

Adapun kekurangan model Project Based Learning menurut Moursound dalam Wena (2011) diantaranya sebagai berikut: 1) organisasi bahan pelajaran, perencanaan dan pelaksanaan pembelajaran proyek sukar dan memerlukan keahlian khusus dari guru, 2) pemecahan masalah kehidupan dalam banyak masih memerlukan sumbangan dari spesialisasi atau disiplin ilmu setiap bidang studi sekalipun diajarkan terpisahkan dari masalah kehidupan nyata, 3) memilih topik yang tepat sesuai kebutuhan siswa, cukup fasilitas dan sumber belajar, bukanlah pekerjaan yang mudah.

Project Based Learning memiliki beberapa tahapan. Salah satu sintaks pembelajaran ini dijelaskan oleh Doppelt (2005) yaitu sebagai berikut:

a. Tujuan Desain (Design Purpose) yaitu mendefinisikan masalah. Siswa memerlukan desain tujuan yang sesuai dengan rumusan masalah yang dibuat. Pencapaian ini mempertimbangkan tujuan, aspek biaya, ketersediaan alat dan bahan, jadwal dan sebagainya.

b. Aspek Inquiri (Field Inquiry) yaitu mendefinisikan aspek inquiri dalam cakupan masalah. Peserta didik harus meneliti dan menganalisis sistem yang sesuai dengan yang mereka kembangkan. Peserta didik juga perlu mengelola dokumentasi dari kegiatan inquiri yang mereka lakukan.

c. Alternatif Pemecahan Masalah (Solution Alternative) yaitu melibatkan pertimbangan alternatif pemecahan masalah terhadap masalah yang dirumuskan. Tahap ini disebut dengan tahap berpikir lateral yang meliputi tiga komponen, yaitu ide, faktor-faktor dan opini orang lain. Peserta didik membutuhkan latihan, sehingga mereka 
merasa bebas untuk berpikir tidak tergantung pada penilaian orang lain.

d. Memilih Solusi yang Tepat (Choosing the Preffered Solution) yaitu memilih pemecahan yang tepat atau yang terbaik. Pilihan dibuat dari berbagai ide yang didokumentasikan dalam tahap ke tiga.

e. Tahap Pelaksanaan (Operation Step) yaitu merencanakan cara operasional untuk mengimplementasikan solusi yang terpilih.

f. Evaluasi (Evaluation) yaitu mengevaluasi keseluruhan proses dan produk yang dihasilkan. Hal ini berupa evaluasi sumatif dan berhubungan dengan tahapan evaluasi formatif yang dilakukan sebagai ide yang telah dikembangkan.

\section{Keterampilan Menulis Bahan Ajar IPA}

Keterampilan menulis merupakan salah satu keterampilan berbahasa yang perlu dilatih oleh seseorang agar mampu menampilkan ide atau gagasan yang dimaksud oleh penulis. Keterampilan menulis menurut Mujiono, dkk (2014) adalah kemampuan seseorang untuk menuangkan buah pikiran, ide, gagasan, dengan mempergunakan rangkaian bahasa tulis yang baik dan benar. Keterampilan atau kemampuan seseorang didapatkan dari kemampuannya dari mendengar, berbicara, dan membaca. Hal ini disebabkan informasi yang didapatkan untuk menulis akan keluar masuk melalui proses menyimak, berbicara, dan membaca.

Keterampilan menulis memiliki berbagai manfaat bagi seseorang. Kegiatan menulis melibatkan proses transformasi komunikasi yang diolah menjadi ide tulisan. Hal ini melibatkan proses berfikir yang tidak sederhana sehingga menjadikan peserta didik lebih kreatif, terampil, dan berani mengemukakan informasi dan ide yang telah didapatkannya. Graves (Mujiono, dkk : 2014) mengemukakan bahwa menulis memiliki manfaat yaitu: (1) menulis menyumbang kecerdasan, (2) menulis mengembangkan daya inisiatif dan kreativitas, (3) menulis menumbuhkan keberanian, dan (4) menulis mendorong kemauan dan kemampuan mengumpulkan informasi.

Bahan ajar merupakan salah satu komponen yang sangat penting dalam suatu kegiatan pembelajaran di kelas untuk mencapai tujuan pembelajaran. Depdiknas (2006) menjelaskan "Bahan ajar adalah materi yang harus dipelajari siswa sebagai sarana untuk mencapai standar kompetensi dan kompetensi dasar. Materi pembelajaran (instructional materials) adalah pengetahuan, keterampilan, dan sikap yang harus diajarkan guru dan dipelajari siswa untuk mencapai standar kompetensi dan kompetensi dasar. Jenis materi pelajaran meliputi fakta, konsep, prinsip, prosedur, dan sikap atau nilai." Bahan ajar perlu dibuat oleh guru agar sesuai dengan karakter dan kebutuhan peserta didik serta relevan dengan kurikulum yang berlaku.

Depdiknas (2008) mengemukakan tujuan penyusunan bahan ajar bahan adalah: a) menyediakan bahan ajar yang sesuai dengan tuntutan kurikulum dengan mempertimbangkan kebutuhan siswa, yakni bahan ajar yang sesuai dengan karakteristik dan setting atau lingkungan sosial siswa, b) membantu siswa dalam memperoleh alternatif bahan ajar di samping buku-buku teks yang terkadang sulit diperoleh, dan c) memudahkan guru dalam melaksanakan pembelajaran. Selain itu, Depdiknas (2008) mengemukakan beberapa manfaat penyusunan bahan ajar, yaitu :

a. Manfaat bagi guru dengan menyusun bahan ajar adalah 1) diperoleh bahan ajar yang sesuai tuntutan kurikulum dan sesuai dengan kebutuhan belajar peserta didik, 2) tidak lagi tergantung kepada buku teks yang terkadang sulit untuk diperoleh, 3) memperkaya ilmu pengetahuan karena dikembangkan dengan menggunakan berbagai referensi, 4) menambah khasanah pengetahuan dan pengalaman guru dalam menulis bahan ajar, 5) membangun komunikasi pembelajaran

Susilawati , Widia Nur Jannah , Dianasari: Efektivitas Project Based Learning terhadap Keterampilan 
yang efektif antara guru dengan peserta didik karena peserta didik akan merasa lebih percaya kepada gurunya. 6) menambah angka kredit jika dikumpulkan menjadi buku dan diterbitkan.

b. Manfaat bagi peserta didik diantaranya:

1) kegiatan pembelajaran menjadi lebih menarik. 2) kesempatan untuk belajar secara mandiri dan mengurangi ketergantungan terhadap kehadiran guru. 3) mendapatkan kemudahan dalam mempelajari setiap kompetensi yang harus dikuasainya.

Ilmu Pengetahuan Alam (IPA) merupakan salah satu mata pelajaran di SD yang mempelajari lingkungan sekitar. Depdiknas (2006) diungkapkan bahwa "IPA berhubungan dengan cara mencari tahu tentang alam secara sistematis, sehingga IPA bukan hanya penguasaan kumpulan pengetahuan yang berupa faktafakta, konsep-konsep, atau prinsip-prinsip saja tetapi juga merupakan suatu proses penemuan". Proses pembelajaran IPA menekankan pada pemberian pengalaman langsung kepada siswa untuk mengembangkan berbagai kompetensi agar mampu menjelajahi dan memahami alam sekitar secara ilmiah. Selain itu, lingkungan terdekat memiliki kebermaknaan yang lebih tinggi jika dibandingkan dengan mengamati fenomena yang jauh dari lingkungan siswa. Oleh karena itu, dalam pembelajaran PjBL ini diarahkan untuk mendapatkan bahan ajar IPA agar relevansinya tinggi sesuai dengan kebutuhan siswa.

\section{Calon Guru SD}

Undang-Undang No.14 Tahun 2005 Tentang Guru dan Dosen Pasal 1 Ayat 1 mendefinisikan Guru adalah pendidik profesional dengan tugas utama mendidik, mengajar, membimbing, mengarahkan, melatih, dan mengevaluasi siswa pada pendidikan anak usia dini, jalur penddikan dasar dan menengah. Sedangkan pada UU No.14 Tahun 2005 Pasal 8 dijelaskan bahwa guru wajib memiliki kualifikasi akademik, kompetensi, sertifikat pendidik, sehat jasmani dan rohani, serta memiliki kemampuan untuk mewujudkan tujuan pendidikan nasional. Hal ini diperjelas dengan UU No.14 Tahun 2005 Pasal 10 yang mengemukakan kompetensi guru sebagaimana dimaksud dalam Pasal 8 meliputi kompetensi pedagogik, kompetensi kepribadian, kompetensi sosial, dan kompetensi profesional yang diperoleh melalui pendidikan profesi.

Definisi calon guru dapat dijelaskan sebagai seseorang yang sedang menempuh pendidikan di Lembaga Pendidikan Tenaga Kependidikan (LPTK) sehingga layak untuk menjadi seorang guru SD yang sesuai dengan peraturan perundang-undangan. Calon guru SD perlu dibekali dengan berbagai pengetahuan dan keterampilan yang akan menjadi tugasnya yaitu seorang pendidik baik secara teori maupun aplikatif. Salah satunya adalah keterampilan menulis bahan ajar yang merupakan bagian dari tugasnya yaitu menyusun bahan ajar yang digunakan untuk proses pembelajaran.

Keterampilan menulis bahan ajar perlu diberikan kepada calon guru sebagai bekal untuk melaksanakan tugas pokok dan fungsinya sebagai seorang pendidik. Bahan ajar perlu disusun oleh guru secara mandiri. Oleh karena itu, proses untuk melatih keterampilan menulis perlu dilakukan secara terus menerus.

\section{METODOLOGI PENELITIAN}

Desain penelitian yang digunakan adalah eksperimen (Single-One Group Pretest-Posttest Design). Desain penelitian diilustrasikan pada Gambar 1.

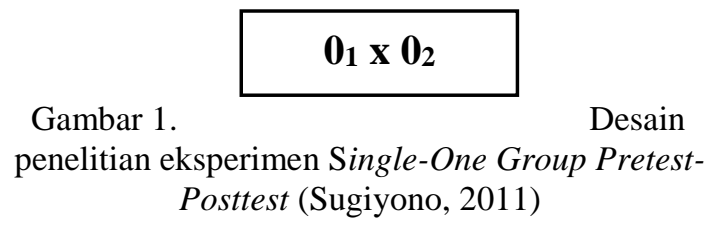

Keterangan:

$\mathrm{X}=$ Implementasi pembelajaran $\mathrm{PjBL}$

$0_{1}=$ pre tes keterampilan menulis

$0_{2}=$ post tes keterampilan menulis 
Penelitian dilaksanakan di Universitas Muhammadiyah Cirebon. Populasi penelitian dipilih secara random sampling dari mahasiswa calon guru SD yang mengontrak mata kuliah "Pembelajaran IPA di SD" di semester IV (Empat), Program Studi Pendidikan Guru Sekolah Dasar (PGSD). Variabel yang diteliti yaitu Project Based Learning (PjBL) sebagai variabel bebas (variable independent), dan keterampilan menulis bahan ajar IPA sebagai variabel terikat (variable dependent).

Instrumen yang digunakan dalam penelitian ini adalah lembar portofolio dan lembar observasi. Selanjutnya data yang diperoleh dalam penelitian ini diolah dan dianalisis menggunakan teknik statistik deskriptif, meliputi rata-rata, standar deviasi, nilai maksimum dan nilai minimum. Penilaian keterampilan mahasiswa calon guru SD dalam menyusun bahan ajar IPA berdasarkan berbagai kriteria yaitu kelayakan isi, kelayakan bahasa, dan kelayakan penyajian. Selanjutnya data keterampilan menulis calon guru SD dikategorikan secara kuantitatif berdasarkan teknik kategorisasi berdasarkan rumus:

$$
\text { Nilai Rata-rata }=\frac{\sum \text { skor perolehan }}{3}
$$

Kemudian hasil skor pengolahan nilai keterampilan menulis calon guru SD tersebut, dikriteriakan dengan kriteria penilaian seperti Tabel 1 .

Tabel 1. Kriteria Penilaian Keterampilan Menulis Bahan Ajar Mahasiswa Calon Guru

\begin{tabular}{lll}
\hline No. & Rentang Skor & Kriteria \\
\hline 1 & $3,01<$ skor $\leq 4,00$ & Terampil \\
2 & $2,01<$ skor $\leq 3,00$ & Cukup Terampil \\
3 & $1,01<$ skor $\leq 2,00$ & Kurang terampil \\
4 & $0<$ skor $\leq 1,00$ & Tidak terampil \\
\hline
\end{tabular}

Selanjutnya data tersebut dianalisis untuk mengetahui peningkatan keterampilan mahasiswa calon guru SD dalam menyusun bahan ajar IPA menggunakan gain ternormalisasi dengan rumus:

$$
\langle g\rangle=\frac{<S \text { post }>-<\text { S pre }>}{<\text { Smax }>-<\text { s pre }>}
$$

Keterangan:

$$
\begin{aligned}
& \langle g\rangle \quad=\text { gain ternormalisasi } \\
& \langle S \text { post }\rangle=\text { skor post test } \\
& \langle S \text { pre }\rangle=\text { skor pretes } \\
& \langle S \text { max }\rangle=\text { skor total }
\end{aligned}
$$

\begin{tabular}{|c|c|}
\hline$\langle g\rangle$ & Kriteria \\
\hline $0,7 \leq \mathrm{g}$ & Tinggi \\
\hline $0,3 \leq \mathrm{g}<0,7$ & Sedang \\
\hline $\mathrm{g}<0,3$ & Rendah \\
\hline
\end{tabular}

Kriteria keberhasilan berdasarkan uji ngain dapat ditentukan dengan indikator seperti Tabel 2.

Selain itu, dalam kegiatan pengolahan data ini digunakan T-Test (one sample ttest) yang dilakukan untuk mengetahui perbedaan mean variable yang dihipotesiskan dan mengetahui tingkat efektivitas dari pembelajaran PjBL terhadap keterampilan menulis bahan ajar IPA calon guru SD.

\section{HASIL PENELITIAN DAN PEMBAHASAN}

1. Efektivitas Project Based Learning (PjBL) terhadap keterampilan menulis bahan ajar IPA Calon Guru SD

a. Hasil Pretes Sebelum diterapkannya PjBL

Pelaksanaan pretes dilakukan pada awal pembelajaran sebelum implementasi $\mathrm{PjBL}$ yaitu pada hari Rabu tanggal 10 Maret 2017 dan rabu tanggal 17 Maret 2017. Dari pertemuan ini, mahasiswa belum memahami konsep bahan ajar yang sesungguhnya. Dari hasil pretes didapat nilai rata-rata indikator pada kelayakan isi adalah 2,82, nilai rata-rata indikator pada kelayakan bahasa adalah 2,91 dan rata-rata indikator pada kelayakan penyajian adalah 2,39 . Dengan demikian rata-rata skor keterampilan menulis bahan ajar berada pada skor 2,71 (cukup terampil). Lebih jelasnya lihat Gambar 2.

Susilawati , Widia Nur Jannah , Dianasari: Efektivitas Project Based Learning terhadap Keterampilan 


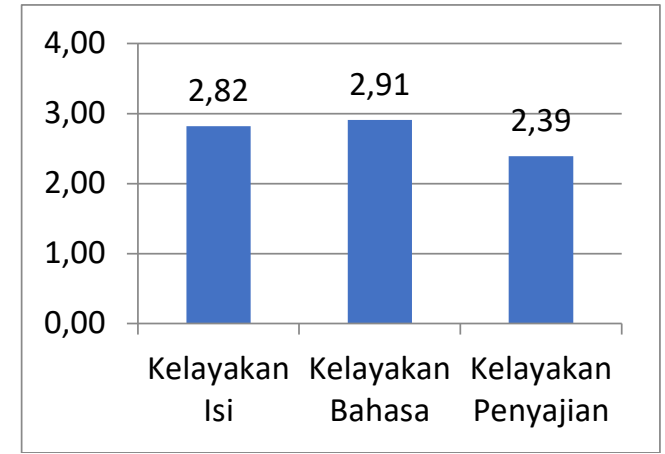

Gambar 2. Nilai Rata-rata Pretes Keterampilan Menulis Bahan Ajar

Pada kategori kelayakan isi, mahasiswa calon guru mendapatkan nilai 2,82 dengan kategori cukup terampil karena sebagian besar sudah mamahami konten materi yang relevan dengan kurikulum yang berlaku yaitu kurikulum 2013 sehingga sesuai dengan Kompetensi Dasar (KD) dan Kompetensi Inti (KI) tetapi belum bisa menyusun materi secara kontekstual. Bahan ajar yang dibuat dalam pretes ini belum relevan dengan kebutuhan dan karakteristik siswa SD. Materi yang disusun pun masih bersifat umum sehingga nilai kekontekstualan materi ajar dinilai masih rendah.

Kategori kelayakan bahasa, mendapat skor 2,91 dengan kategori cukup terampil. Hal ini disebabkan pada aspek ini, beberapa mahasiswa calon guru sudah bahan ajar sudah menunjukkan nilai diatas 3 yang menunjukkan kategori terampil. Pada sebagian besar mahasiswa sudah menunjukkan nilai yang baik pada aspek lugas, komunikatif, dialogis dan interaktif. Namun pada aspek kesesuaian dengan perkembangan peserta didik, kesesuaian dengan kaidah bahasa Indonesia, serta konsistensi penggunaan istilah, simbol dan / atau ikon masih dinilai kurang.

Kemudian pada kategori kelayakan penyajian, skor yang didapat adalah 2,39. Walaupun masih dalam kategori cukup terampil, namun kategori ini cenderung jauh lebih rendah dari aspek lainnya. Hal ini disebabkan rendahnya nilai pendukung penyajian yang disusun tidak konsisten seperti tidak semua mahasiswa calon guru menuliskan pengantar pada bagian awal, contoh soal, lembar kerja dan rangkuman pada setiap pembelajaran yang disajikan dalam bahan ajar. Mahasiswa calon guru cenderung membuat sendiri konsep bahan ajar yang diinginkan tanpa melihat berbagai aspek yang harus ada pada setiap pembelajaran. Dengan demikian, nilai aspek ini cenderung rendah.

Setelah mengetahui nilai pretes setiap indikator langkah selanjutnya adalah menjumlahkan nilai pada setiap indikator dan didapat nilai akhir pretes. Nilai akhir pretes dianalisis menggunakan microsoft excel 2010. Adapun analisis hasil dapat dilihat pada Tabel 3.

Tabel 3. Hasil Analisis Data Pretes Keterampilan Menulis Bahan Ajar

\begin{tabular}{lc}
\hline \multicolumn{1}{c}{ Statistik } & Nilai Statistik Pretes \\
\hline Sampel & 31 \\
Nilai Minimum & 2,25 \\
Nilai Maximum & 3,12 \\
Nilai Rata-rata & 2,71 \\
Standar Deviasi & 0,31 \\
\hline
\end{tabular}

Berdasarkan Tabel 3 di atas, maka dapat disimpulkan bahwa dari 31 orang didapat nilai minimum pada hasil pretes sebesar 2,25 (kategori cukup terampil) dan nilai maksimum hasil pretes sebesar 3,12 (kategori terampil). Sedangkan rata-rata pada hasil pretes adalah 2,71 (kategori cukup terampil) dan standar deviasinya sebesar 0,31. Selain itu, frekuensi perolehan penilaian pretes keterampilan menulis bahan ajar IPA mahasiswa calon guru SD dapat dilihat pada Tabel 4.

Tabel 4. Frekuensi Hasil Pretes Keterampilan Menulis Bahan Ajar

\begin{tabular}{|c|c|c|c|}
\hline Niloi & Vor & Fnl & \\
\hline $301-400$ & Teramnil & 7 & $226 \%$ \\
\hline $2,01-3,00$ & $\begin{array}{l}\text { Cukup } \\
\text { Terampil }\end{array}$ & 24 & $77,4 \%$ \\
\hline $1,01-2,00$ & $\begin{array}{l}\text { Kurang } \\
\text { terampil }\end{array}$ & 0 & $0 \%$ \\
\hline $0,00-1,00$ & $\begin{array}{l}\text { Tidak } \\
\text { Terampil }\end{array}$ & 0 & $0 \%$ \\
\hline \multicolumn{2}{|c|}{ Total } & 31 & $100 \%$ \\
\hline
\end{tabular}

b. Pelaksanaan Treatmen dengan Menggunakan PjBL

Setelah melakukan pretes, langkah kedua adalah melaksanakan treatmen 
dengan menggunakan PjBL sebanyak 3 kali pada hari Rabu tanggal 24 Maret 2017, tanggal 31 Maret 2017, dan 7 Juni 2017. Treatmen ini dilaksanakan sesuai dengan langkah-langkah pembelajaran $\mathrm{PjBL}$ seperti yang terlihat pada Tabel 5 .

Tabel 5. Langkah-langkah PjBL di Kelas

\begin{tabular}{|c|c|c|}
\hline No & $\begin{array}{c}\text { Tahapan } \\
\text { PjBL }\end{array}$ & Pelaksanaan Implementasi \\
\hline 1. & $\begin{array}{l}\text { Merancang } \\
\text { Tujuan } \\
\text { (Design } \\
\text { Purpose) } \\
\text { yaitu } \\
\text { mendefinisik } \\
\text { an masalah }\end{array}$ & $\begin{array}{l}\text { Pada tahapan ini, mahasiswa } \\
\text { melakukan kegiatan diskusi } \\
\text { yang berkaitan dengan masalah- } \\
\text { masalah pembelajaran di SD. } \\
\text { Masalah-masalah tersebut } \\
\text { diantaranya pembelajaran yang } \\
\text { disajikan kurang efektif dan } \\
\text { interaktif. Selain itu, tujuan } \\
\text { pembelajaran lebih sulit dicapai } \\
\text { oleh siswa terutama pada } \\
\text { pembelajaran IPA. Pada langkah } \\
\text { ini juga, mahasiswa membatasi } \\
\text { permasalahan pembelajaran } \\
\text { yang bersumber pada bahan ajar. }\end{array}$ \\
\hline 2. & $\begin{array}{l}\text { Mengajukan } \\
\text { pertanyaan } / i \\
\text { nquiry (Field } \\
\text { Inquiry) } \\
\text { yaitu } \\
\text { mendefinisik } \\
\text { an aspek } \\
\text { inquiri dalam } \\
\text { cakupan } \\
\text { masalah }\end{array}$ & $\begin{array}{l}\text { Langkah ini dilakukan oleh } \\
\text { mahasiswa dengan menganalisis } \\
\text { masalah bahan ajar IPA. } \\
\text { Berbagai masalah yang } \\
\text { berkaitan dianalisis } \\
\text { penyebabnya apakah bersumber } \\
\text { dari siswa, guru, atau } \\
\text { pemerintah. Pada tahapan ini } \\
\text { juga, mahasiswa mendapatkan } \\
\text { sejumlah pertanyaan yang } \\
\text { berkaitan dengan rendahnya } \\
\text { kemampuan guru dalam } \\
\text { menyusun bahan ajar sehingga } \\
\text { menyebabkan pembelajaran di } \\
\text { kelas kurang efektif. }\end{array}$ \\
\hline 3. & $\begin{array}{l}\text { Mengajukan } \\
\text { alternatif } \\
\text { pemecahan } \\
\text { masalah } \\
\text { (solution } \\
\text { alternative) } \\
\text { yaitu } \\
\text { melibatkan } \\
\text { pertimbanga } \\
\text { n alternatif } \\
\text { pemecahan } \\
\text { masalah } \\
\text { terhadap } \\
\text { masalah } \\
\text { yang } \\
\text { dirumuskan }\end{array}$ & $\begin{array}{l}\text { Tahapan yang dilakukan oleh } \\
\text { mahasiswa pada langkah ini } \\
\text { yaitu dengan beberapa alternatif } \\
\text { pemecahan masalah yang harus } \\
\text { diselesaikan. Mahasiswa sebagai } \\
\text { calon guru mendiskusikan } \\
\text { pengertian bahan ajar dan } \\
\text { menganalisis berbagai cara } \\
\text { untuk dapat menyusun bahan } \\
\text { ajar diantaranya dengan } \\
\text { menganalisis model-model } \\
\text { pengembangan bahan ajar yaitu } \\
\text { model "ASSURE" dan } \\
\text { "ADDIE". Berdasarkan model- } \\
\text { model tersebut, mahasiswa } \\
\text { mengkaji alternatif yang paling } \\
\text { memudahkannya dalam } \\
\text { menyusun bahan ajar secara } \\
\text { sederhana. }\end{array}$ \\
\hline
\end{tabular}

\begin{tabular}{|c|c|c|}
\hline No & $\begin{array}{c}\text { Tahapan } \\
\text { PjBL }\end{array}$ & Pelaksanaan Implementasi \\
\hline 4. & $\begin{array}{l}\text { Memilih } \\
\text { solusi yang } \\
\text { tepat } \\
\text { (Choosing } \\
\text { the Preffered } \\
\text { Solution): } \\
\text { memilih } \\
\text { salah satu } \\
\text { solusi } \\
\text { alternatif } \\
\text { yang tepat }\end{array}$ & $\begin{array}{l}\text { Berdasarkan langkah } \\
\text { sebelumnya, langkah ini } \\
\text { dilakukan oleh mahasiswa } \\
\text { dengan memilih model } \\
\text { "ASSURE" sebagai langkah } \\
\text { untuk menyusun bahan ajar IPA } \\
\text { sesuai dengan kurikulum dan } \\
\text { kebutuhan siswa. Adapun materi } \\
\text { IPA yang disusun berdasarkan } \\
\text { kurikulum } 2013 \text { yaitu kurikulum } \\
\text { terbaru yang menggunakan tema } \\
\text { dalam setiap pembelajaran. } \\
\text { Selain itu, sebagai bahan latihan } \\
\text { menulis, mahasiswa calon guru } \\
\text { menentukan tema "Berbagai } \\
\text { Pekerjaan" yang ada pada kelas } \\
4 \text { semester } 1 \text { untuk dibuat bahan } \\
\text { ajar sehingga memudahkan } \\
\text { mahasiswa dalam menyusun } \\
\text { bahan ajar yang kontekstual dan } \\
\text { sesuai dengan kebutuhan siswa } \\
\text { di SD. }\end{array}$ \\
\hline 5. & $\begin{array}{l}\text { Tahap } \\
\text { Pelaksanaan } \\
\text { (Operation } \\
\text { Step): } \\
\text { Merencanaka } \\
\text { n metode } \\
\text { untuk } \\
\text { implementasi } \\
\text { solusi yang } \\
\text { dipilih. }\end{array}$ & $\begin{array}{l}\text { Pada tahapan ini, mahasiswa } \\
\text { calon guru dibuat } 3 \text { kelompok } \\
\text { besar sesuai dengan subtema } \\
\text { yang ada pada tema "Berbagai } \\
\text { Pekerjaan" dan mulai menyusun } \\
\text { bahan ajar sesuai dengan } \\
\text { komponen penyusunan bahan } \\
\text { ajar. Adapun masing-masing } \\
\text { kelompok menyusun bahan ajar } \\
\text { dengan subtema "Jenis-jenis } \\
\text { Pekerjaan", "Barang dan Jasa", } \\
\text { dan "Pekerjaan Orang Tuaku" }\end{array}$ \\
\hline 6. & $\begin{array}{l}\text { Evaluasi } \\
\text { (Evaluation): } \\
\text { mengevaluas } \\
\text { i keseluruhan } \\
\text { proses dan } \\
\text { produk yang } \\
\text { dihasilkan. }\end{array}$ & $\begin{array}{l}\text { Langkah ini dilakukan dengan } \\
\text { mengevaluasi hasil bahan ajar } \\
\text { yang telah dibuat oleh } \\
\text { mahasiswa calon guru. }\end{array}$ \\
\hline
\end{tabular}

c. Hasil Postes setelah Diterapkannya $\mathrm{PjBL}$

Postes dilaksanakan pada saat setelah treatmen PjBL, yaitu pada hari Rabu, tanggal 14 Juni 2017 dan tanggal 21 Juni 2017. Hasil postes dilihat dari setiap indikator keterampilan menulis buku ajar, yaitu kelayakan isi, kelayakan bahasa, dan kelayakan penyajian. Hasil nilai rata-rata dari kelayakan isi yaitu sebesar 3,77 (kategori terampil), kelayakan bahasa sebesar 3,84 (kategori terampil) dan nilai 
rata-rata dari kelayakan penyajian sebesar 3,88 (kategori terampil).

Jika dilihat dari hasil nilai rata-rata postes maka terlihat peningkatan pada setiap indikatornya yaitu pada kelayakan isi meningkat sebesar 0,95, kelayakan bahasa meningkat sebesar 0,93 dan kelayakan penyajian meningkat sebesar 1,49. Peningkatan yang lebih signifikan terlihat pada indikator kelayakan penyajian. Perolehan hasil pretes dan postes keterampilan menulis bahan ajar calon guru SD dapat dilihat pada Gambar 3.

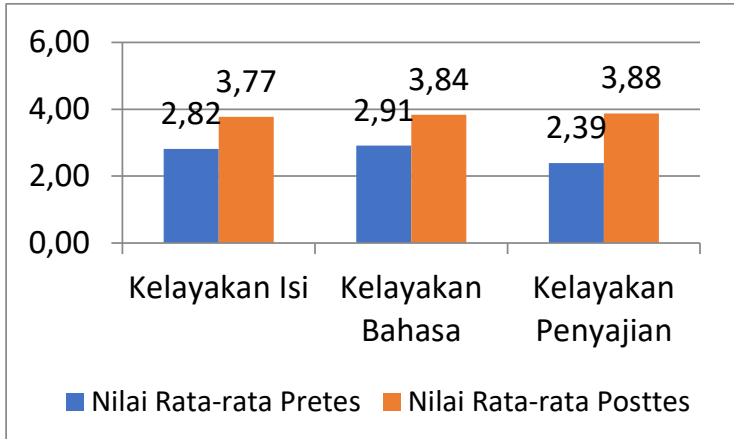

Gambar 3. Peningkatan Nilai Rata-Rata Pretes dan Postes Keterampilan Menulis Bahan Ajar

Peningkatan yang terjadi pada kategori kelayakan isi disebabkan bahan ajar yang dibuat dalam postes ini lebih relevan dengan kurikulum 2013 dan lebih relevan dengan kebutuhan dan karakteristik siswa SD. Materi yang disusun sudah mengandung nilai kekontekstualan yang lebih baik jika dibandingkan dengan pretes.

Hasil postes dapat dianailisis menggunakan microsoft excel 2010, hasil analisisnya dapat dilihat pada Tabel 6 .

Tabel 6. Hasil Analisis Data Postes Keterampilan Menulis Bahan Ajar

\begin{tabular}{lc}
\hline \multicolumn{1}{c}{ Statistik } & Nilai Statistik Postes \\
\hline Sampel & 31 \\
Nilai Minimum & 3,67 \\
Nilai Maximum & 3,97 \\
Nilai Rata-rata & 3,83 \\
Standar Deviasi & 0,10 \\
\hline
\end{tabular}

Berdasarkan Tabel 6 maka dapat disimpulkan bahwa rata-rata hasil postes keterampilan menulis bahan ajar adalah 3,83 (kategori terampil), nilai minimumnya adalah 3,67 (kategori terampil), nilai maksimum adalah 3,77 (kategori terampil), dan standar deviasi adalah sebesar 0,10. Frekuensi perolehan penilaian posttes keterampilan menulis bahan ajar IPA mahasiswa calon guru SD dapat dilihat pada Tabel 7.

Tabel 7. Frekuensi Hasil Pretes Keterampilan Menulis Bahan Ajar

\begin{tabular}{|c|c|c|c|}
\hline Nilai & Kategori & Frekuensi & Persentase \\
\hline $3,01-4,00$ & Terampil & 31 & $100 \%$ \\
\hline $2,01-3,00$ & $\begin{array}{l}\text { Cukup } \\
\text { Terampil }\end{array}$ & 0 & $0 \%$ \\
\hline $1,01-2,00$ & $\begin{array}{l}\text { Kurang } \\
\text { terampil }\end{array}$ & 0 & $0 \%$ \\
\hline $0,00-1,00$ & $\begin{array}{l}\text { Tidak } \\
\text { Terampil }\end{array}$ & 0 & $0 \%$ \\
\hline \multicolumn{2}{|c|}{ Total } & 31 & $100 \%$ \\
\hline
\end{tabular}

Setelah kita mengetahui hasil dari pretes dan postes baik rata-rata maupun standar deviasinya maka langkah selanjutnya adalah menghitung gain ternormalisasi (n-gain) untuk melihat peningkatan setelah dilakukan treatmen. Mengitung N-Gain pada penelitian ini menggunakan microsoft excel 2010 yang disesuaikan dengan rumus N-Gainnya. Setelah dihitung, maka dapat diketahui nilai $\mathrm{N}$-Gain pada setiap indikator keterampilan menulis bahan ajar IPA, lihat Tabel 8 .

Tabel 8. Hasil N-Gain Keterampilan Menulis Bahan Ajar

\begin{tabular}{lcc}
\hline \multicolumn{1}{c}{ Indikator } & Nilai N-Gain & Katagori \\
\hline Kelayakan Isi & 0,80 & Tinggi \\
Kelayakan Bahasa & 0,87 & Tinggi \\
$\begin{array}{l}\text { Kelayakan } \\
\text { penyajian }\end{array}$ & 0,93 & Tinggi \\
\hline Rata-rata N-Gain & 0,87 & Tinggi \\
\hline
\end{tabular}

Berdasarkan Tabel 8 maka dapat disimpulkan bahwa nilai gain dari setiap indikator keterampilan menulis bahan ajar IPA adalah tinggi dengan nilai pada kelayakan isi adalah 0,80 , pada kelayakan bahasa adalah 0,87 dan pada kelayakan penyajian adalah 0,93 . Lebih jelasnya dapat dilihat pada Gambar 4. 


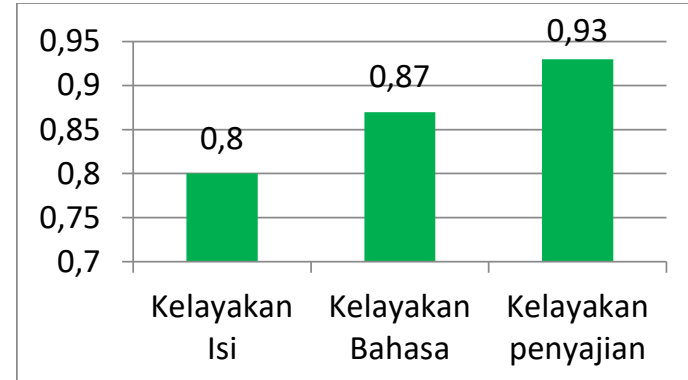

Gambar 4. Hasil N-Gain Keterampilan Menulis Bahan Ajar IPA

Hasil penilaian efektivitas $\mathrm{PjBL}$ yang mengarah kepada peningkatan keterampilan menulis bahan ajar IPA calon guru dapat dilihat pada Tabel 9.

Tabel 9. Hasil Penilaian Efektivitas PjBL

(peningkatan) dalam Menulis Bahan Ajar IPA

\begin{tabular}{llll}
\hline \multicolumn{1}{c}{ Kriteria } & Pretes & Postes & N-Gain \\
\hline $\begin{array}{l}\text { Kelayakan isi } \\
\text { Kelayakan }\end{array}$ & 2,82 & 3,77 & 0,80 \\
$\begin{array}{l}\text { Bahasa } \\
\text { Kelayakan } \\
\text { penyajian }\end{array}$ & 2,91 & 3,84 & 0,87 \\
\hline Rata-rata & 2,39 & 3,88 & 0,93 \\
\hline
\end{tabular}

Berdasarkan Tabel 9 dapat disimpulkan bahwa setiap indikator keterampilan menulis bahan ajar yaitu, kelayakan isi, kelayakan bahasa, serta kelayakan penyajian terdapat peningkatan dilihat dari nilai gain yang diperoleh. Pemerolehan tersebut adalah: Kelayakan isi 0,80, kelayakan bahasa 0,87 , dan kelayakan penyajian 0,93 .

\section{Hasil Uji Koefisien Regresi Sederhana Efektivitas Project Based Learning (PjBL) terhadap Keterampilan Menulis Bahan Ajar IPA Calon Guru SD (uji t)}

Setelah mendapatkan hasil N-Gain dan hasil angket respon siswa, kemudian langkah selanjutnya adalah mencari uji koefisien regresi sederhana (uji-t). dengan menggunakan SPSS 20. Uji ini digunakan untuk mengetahui apakah variabel independen $(\mathrm{x})$ berpengaruh signifikan terhadap variabel dependen (y) Adapun hasil pengolahan data dengan menggunakan SPSS 20 dapat dilihat pada Tabel 10 di bawah ini:
Tabel 10. Model Summary

\begin{tabular}{lrrrr}
\hline Model & R & R Square & $\begin{array}{c}\text { Adjusted R } \\
\text { Square }\end{array}$ & $\begin{array}{l}\text { Std. Error of } \\
\text { the Estimate }\end{array}$ \\
\hline 1 &, $831^{\mathrm{a}}$ &, 691 &, 680 &, 58467 \\
\hline a. Predictors: (Constant), PjBL & & &
\end{tabular}

Berdasarkan Tabel 10 (Model Summary) menjelaskan besarnya nilai korelasi/hubungan $(\mathrm{R})$ yaitu sebesar 0,831 dan dijelaskan hasil R Square atau koefisien determinan (R2) sebesar 0,691 atau 69,1 yang artinya bahwa pengaruh model $\mathrm{PjBl}$ terhadap keterampilan menulis bahan ajar IPA sebesar 69,1\%. Adapun 30,9 dipengaruhi oleh faktor lain diluar dari model PjBL (diluar variabel $\mathrm{x}$ ).

Setelah didapat hasil model summary, kemudian output kedua didapat hasil Anova. Hasil Anova ini untuk menjelaskan apakah ada pengaruh yang nyata (signifikan) variabel $\mathrm{PjBL}(\mathrm{x})$ terhadap variabel keterampilan menulis bahan ajar. Hasilnya dapat dilihat pada Tabel 11.

Tabel 11. Anova

\begin{tabular}{lrrrrr}
\hline \multirow{2}{*}{ Model } & Sum of & \multirow{2}{*}{ Df } & $\begin{array}{c}\text { Mean } \\
\text { Square }\end{array}$ & F & \multirow{2}{*}{ Sig. } \\
\hline Regression & 22,154 & 1 & 22,154 & 64,807 &, $000^{\mathrm{b}}$ \\
Residual & 9,913 & 29 &, 342 & & \\
Total & 32,067 & 30 & & & \\
\hline
\end{tabular}

a. Dependent Variable: keterampilan

b. Predictors: (Constant), PjBL

Berdasarkan Tabel 11 terlihat bahwa Fhitung $=64,807$ dengan tingkat signifikan / probabilitas $0,000<0,05$ maka model regresi dapat dipakai untuk memprediksi variabel keterampilan menulis bahan ajar calon guru. Jika dilihat dari Tabel 5.9 dan Tabel 5.10, maka hasil dari perhutungan regresi dengan menggunakan SPSS 20, terdapat output ketiga yaitu coefficients. Oleh karena itu agar lebih jelas maka dapat dilihat pada Tabel 12 di bawah ini:

Tabel 12. Coefficients ${ }^{\mathrm{a}}$

\begin{tabular}{|c|c|c|c|c|c|}
\hline \multirow[t]{2}{*}{ Model } & \multicolumn{2}{|c|}{$\begin{array}{l}\text { Unstandardized } \\
\text { Coefficients }\end{array}$} & \multirow{2}{*}{$\begin{array}{l}\text { Standardized } \\
\text { Coefficients } \\
\text { Beta }\end{array}$} & \multirow[t]{2}{*}{$\mathrm{t}$} & \multirow[t]{2}{*}{ Sig. } \\
\hline & B & $\begin{array}{l}\text { Std. } \\
\text { Error }\end{array}$ & & & \\
\hline $\begin{array}{l}\text { (Consta } \\
\mathrm{nt})\end{array}$ & $-1,814$ & 4,985 & &,- 364 & ,719 \\
\hline $\mathrm{PjBL}$ & 10,279 & 1,277 & ,831 & 8,050 &, 000 \\
\hline
\end{tabular}


Berdasarkan Tabel 12 di atas, terdapat kolom B pada Constan (a) adalah 1,814, sedangkan nilai PjBL (b) adalah 10,279, sehingga persamaan regresinya dapat ditulis $Y=\mathbf{a}+\mathbf{b X}$ atau $1,814+\mathbf{1 0 , 2 7 9 X}$. Dari persamaan tersebut dapat diterjemahkan bahwa konstanta sebesar 1,814 menyatakan bahwa jika tidak ada nilai PjBL maka nilai keterampilan menulis bahan ajar IPA sebesar 1,814. Kemudian jika koefisien regresi X sebesar 10,279 menyatakan bahwa setiap penambahan 1 nilai PjBL, maka nilai keterampilan menulis bahan ajar IPA bertambah sebesar 10,279 .

Pada Tabel 12 selain menggambarkan persamaan regresi, dapat dilihat juga uji signifikansi dengan uji $t$ yaitu untuk mengetahui apakah ada pengaruhnya yang nyata antara variabel $\mathrm{PjBL}(\mathrm{X})$ terhadap variabel keterampilan menulis bahan ajar IPA. Adapun hasil hipotesis dari hasil tersebut adalah :

1. Jika $\pm \mathrm{t}_{\text {hitung }}< \pm \mathrm{t}_{\text {tabel, }}$ maka $\mathrm{H}_{0}$ diterima dan $\mathrm{H}_{1}$ ditolak.

2. Jika $\pm t_{\text {hitung }}> \pm t_{\text {tabel}}$, maka $\mathrm{H}_{0}$ ditolak dan $\mathrm{H}_{1}$ diterima.

$\mathrm{H}_{0}$ : tidak ada pengaruh yang nyata (signifikan) variabel model PjBL (X) terhadap variabel Keterampilan Menulis Bahan Ajar IPA

$\mathrm{H}_{1}$ : ada pengaruh yang nyata (signifikan) variabel model PjBL (X) terhadap variabel Keterampilan Menulis Bahan Ajar IPA

Nilai $t_{\text {hitung }}=8,050$ dan tabel dicari dengan tabel distribusi $t$ pada taraf kepercayaan 95\% $(\alpha=5 \%$, karena uji $\mathrm{t}$ bersifat dua sisi, maka nilai $\alpha / 2=5 \% / 2=$ $0,025)$ dan derajat bebas (df) $=\mathrm{n}-2=31-2$ $=29$, sehingga $\mathrm{t}(0,025 ; 29)=2,045$. Karena t hitung sebesar 8,050 lebih besar dari $(>)$ 2,045, sehingga dapat disimpulkan bahwa maka $\mathrm{H}_{0}$ ditolak dan $\mathrm{H}_{1}$ diterima yang berarti bahwa ada pengaruh yang nyata (signifikan) variabel $\mathrm{X}$ yaitu model $\mathrm{PjBL}$ terhadap variabel $\mathrm{Y}$ yaitu keterampilan menulis bahan ajar IPA. Hal ini menunjukkan model pembelajaran berbasis proyek atau Project Based Learning (PjBL) membantu mahasiswa dalam belajar pengetahuan dan keterampilan yang kokoh dan bermakna-guna (meaningful-use) yang dibangun melalui tugas-tugas dan pekerjaan yang otentik (Cord, 2001; Hung \& Wong, 2000; Myers \& Botti, 2000; Marzano, 1992 dalam Rais:2010).

\section{KESIMPULAN}

Berdasarkan penelitian yang telah dilaksanakan dan hasil analisis data yang telah dilakukan, dapat disimpulkan bahwa Project Based Learning (PjBL) efektif digunakan untuk meningkatkan keterampilan menulis bahan ajar IPA Calon Guru SD. Hal ini dibuktikan dengan hasil penilaian yang meningkat signifikan dari 2,71 (kategori cukup terampil) menjadi 3,83 (kategori terampil) serta didukung oleh hasil $\mathrm{n}$-Gain yang tinggi yaitu 0,87 . Selain itu, berdasarkan uji $\mathrm{T}$ diketahui bahwa t hitung sebesar 8,050 lebih besar dari t tabel yaitu 2,045, sehingga $\mathrm{H}_{0}$ ditolak dan $\mathrm{H}_{1}$ diterima yang berarti bahwa ada pengaruh yang nyata (signifikan) variabel $\mathrm{X}$ yaitu model $\mathrm{PjBL}$ terhadap variabel $\mathrm{Y}$ yaitu keterampilan menulis bahan ajar IPA.

\section{DAFTAR PUSTAKA}

Depdiknas. (2006). Kurikulum Tingkat Satuan Pendidikan. Jakarta: Depdiknas.

Depdiknas. (2008). Pengembangan Bahan Ajar. Jakarta: Depdiknas.

Doppelt, Y. (2005). Assessment of Project Based Learning in a Mechatronicts Context. Journal of Technology Education. Volume 16, number 2.

Ghanney, RA. (2008). The Use of Instructional Materials in the Teaching and Learning of Environmental Studies in Primary Schools: A Case Study of Winneba. International Journal of Educational Research. Vol. 4 (1) 2008: pp. 135-140. ISSN: 1595-8485.

Mujiono, dkk. (2014). Pengembangan Bahan Ajar Menulis Berbasis Nilai- 
Nilai Karakter Islam untuk MTs. Jurnal J-Simbol (Bahasa, Sastra, dan Pembelajarannya). Hal 1-18.

Rais. (2010). Project-Based Learning: Inovasi Pembelajaran yang Berorientasi Soft skills. Prosiding pada Seminar Nasional Pendidikan Teknologi dan Kejuruan Fakultas Teknik Universitas Negeri Surabaya. 11 Desember 2010. Surabaya. Hal 1-17.

Sembiring, D. (2007). Upaya Peningkatan Kemampuan Menulis dan Kualitas Karya Tulis Ilmiah Guru. Artikel.

Sinaga, P. (2015). Desain Model Pembelajaran untuk Meningkatkan Keterampilan Calon Guru Fisika dalam Menulis Materi Ajar. Prosiding Seminar Nasional Fisika (E-Journal) SNF2015 http://snf-unj.ac.id/kumpulanprosiding/snf2015/. Volume IV, Oktober 2015 p-ISSN: 2339-0654 eISSN: 2476-9398.

Sugiyono. (2011). Metode Penelitian Pendidikan. Bandung: Alfabeta.

Sukerni, P. (2014). Pengembangan Buku Ajar Pendidikan IPA Kelas IV Semester I SD No. 4 Kaliuntu dengan Model Dick and Carey. Jurnal Pendidikan Indonesia. ISSN: 2303-288X Vol. 3, No. 1, April 2014. Hal 386-396.

Tiantong, M \& Sumalee Siksen. (2013). The Online Project-based Learning Model Based on Student's Multiple Intelligence. International Journal of Humanities and Social Science. Vol. 3 No. 7; April 2013. PP. 204-211.

Undang-Undang Republik Indonesia No.14 Th 2005 Tentang Guru dan Dosen Pasal 1, Pasal 8, dan Pasal 10.

Undang-Undang Sistem Pendidikan Nasional No. 20 tahun 2003 Pasal 40 Ayat 2.

Wang, dkk. (2015). Let's Go Traveling Project-Based Learning in a Taiwanese Classroom. International Journal of Information and Education Technology. Vol. 5, No. 2, February 2015. Hal 84-88.

Wena, M. (2011). Strategi Pembelajaran

Kontemporer. Jakarta: Bumi Aksara. 